\title{
REFORM OF PRIVATE INTERNATIONAL LAW IN COUNTRIES SUCCESSORS OF THE FORMER YUGOSLAVIA NEW LEGAL CHALLENGES V. LEGAL TRADITION*
}

\begin{abstract}
Countries successors of the former Socialist Federal Republic of Yugoslavia have achieved an immense progress in reforming their legal systems, despite unfortunate war consequences. The ratio behind this process is, firstly, to adhere to the new international obligations (especially European Convention for the Protection of Human Rights and Fundamental Freedoms). Secondly, to adjust, as far as possible, to the European Union law (acquis communaitaire).

One of the similarities of all these countries is the clear intention to reform their Private International Law. In the era of globalization, wide circulation of persons, goods, services, foreign judicial and arbitral decisions and other public documents, conflict of law rules and rules on international jurisdiction in private law relations are becoming more and more important in daily life and legal practice. There is a strong need for regional harmonization of the rules of Private International Law. There is also a need for specific expertise in this field of law, perhaps specialization of judges who would also train other colleagues, in order to have a coherent, consistent and stabile legal system and to enjoy respect in international community.

This paper will focus on Private International Law reform in the countries successors of the former SFRY. It will try to show that it is possible to reconcile the need to do the extensive legal reform but also to retain the basic principles of the former joint legal tradition.
\end{abstract}

Keywords: Private International Law Reform; Private International Law Act; former SFRY; European Convention for the Protection of Human Rights and Fundamental Freedoms; European Union.

* This paper has been presented at the International Scientific Conference Legal Tradition and New Legal Challenges, held on October 3rd and 4th, 2019, at the University of Novi Sad Faculty of Law. 


\section{INTRODUCTION}

Countries successors of the former Socialist Federal Republic of Yugoslavia (Slovenia, Croatia, Serbia, Montenegro, Northern Macedonia and Bosnia and Herzegovina) have achieved an immense progress in reforming their legal systems, despite unfortunate war consequences and challenges stemming from the transition from one economic and political system to another. A number of new laws have been promulgated in order to replace the ones adopted by the former Socialist Federal Republic of Yugoslavia (hereinafter referred to as „SFRY”).

The ratio behind this process is, firstly, to adjust their legal systems to the new economic and social needs, to the new political and economic reality, since the countries of the former Yugoslavia have abandoned socialist system based on the state governed economy. This ,transition" is still ongoing.

Secondly, the newly established states had to adhere to numerous international obligations, especially to the European Convention for the Protection of Human Rights and Fundamental Freedoms as members of the Council of Europe. As new independent states, they needed to be established and recognized as states governed by the principles of democracy, rule of law and respect for human rights and freedoms.

Furthermore, they try to adjust their internal legal systems to the European Union law (acquis communaitaire), since all of them have formally expressed their intention to accede to this regional international organization.

One of the similarities of all these countries is the clear intention to reform their Private International Law. In the era of globalization ${ }^{2}$, wide circulation of persons, goods, services, foreign judicial decisions, arbitral awards and other public documents, conflict of law rules and rules on international jurisdiction in private law relations are becoming more and more important in daily life and legal practice. Therefore, clear and strong need for regional harmonization of the rules of Private International Law came as a natural consequence of the mentioned processes.

All the mentioned countries, except Bosnia and Herzegovina, took some steps to reform their former common Private International Law Act, which is the „old" Yugoslav Law on Resolution of Conflict of Laws with Other Countries in certain Relations-PIL Act ${ }^{3}$ of 1982. This common legislation has survived the former state, the former economic and political state system. The Private International Law Act of SFRY served unchanged for almost 25 years in all the states of the former Yugoslavia, regardless of the fact that its state of origin ceased to exist. This Act is still in force in Bosnia and Herzegovina and in Serbia.

${ }^{2}$ Vilim Bouček, Europsko međunarodno privatno pravo u eurointegracijskom procesu i harmonizacija hrvatskog međunarodnog privatnog prava, Zagreb 2009, 15-22.

${ }^{3}$ Official gazette of the SFRY No. 43/1982 and 72/1982. 
One of the values of the old PIL Act was that it was drafted exclusively by the best scholars of Private International Law of that time, representing two distinguished Law Faculties and two scientific institutes (Institute for Comparative Law and Institute for International Law and International Relations) in Belgrade and Zagreb. The famous professors and arbitrators, with scientific work in the area of Private International Law and with extensive international practical experience, developed the rules contained in the PIL Act. In parliamentary procedure, the drafted material was subjected to only two minor changes. Such result proves that the legislator put enormous trust into the working group of experts and appreciated the efforts they put in the project.

Preparing good and lasting laws requires erudition and participation of experienced practitioners. This Act was rather short and clear, with the proper level of abstractness of its rules. These features were qualities of the old Yugoslav legislative tradition. The core principles of PIL Act are: proximity (closest connection), reciprocity, pacta sunt servanda (international agreements must be implemented and obeyed), non-discrimination, sovereign equality of all states and non-intervention in matters which are essentially within the domestic jurisdiction of other states ${ }^{4}$. These principles were retained in the new legislative efforts. They guarantee the preservation of good features of the former joint legal tradition but also the harmonization with major regional legislative projects.

\section{INTERNATIONAL TREATIES AND CASE LAW OF EUROPEAN COURTS AS A SOURCE OF LAW}

One of the basic principles of the former Yugoslav constitutional law was the principle of ,legality”, i.e. in exercising their function; courts are bound only by the constitution, laws (zakoni) and other rules (propisi) but not by the case law (precedents) $)^{5}$. However, the substantial coherence and quality of court practice (case law) is very important since the legal certainty and uniformity of the court judgements is one of the general core legal values.

Accession to the Council of Europe is a recognition that a certain member country is based on common European democratic values, the principle of rule of law and respect for human rights and freedoms. The most challenging task for the new democracies is to adhere to obligation to respect human rights and fundamental freedoms enshrined in the European Convention of Human Rights and

\footnotetext{
${ }^{4}$ Maja Stanivuković, Mirko Živković, „International Encyclopedia of Laws”, Kluwer Law International, Hague-London 2001, 20-21.

${ }^{5}$ M. Stanivuković, M. Živković, „International Encyclopedia of Laws”, Kluwer Law International, Hague-London 2001, 44.
} 
Fundamental Freedoms (European Convention) ${ }^{6}$. The final authority to confirm the respect for human rights and freedoms guaranteed by the European Convention is the European Court of Human Rights (ECHR) in Strasbourg. Only the case law of the Strasbourg Court give the proper interpretation of the provisions of the European Convention and give guidance to the state authorities how to act in order to respect it. The lack of proper and continued education about human rights, especially about the Strasbourg system of the protection of human rights and fundamental freedoms, result in the fact that more than $90 \%$ of applications sent to the Strasbourg court are declared inadmissible or manifestly ill founded ${ }^{7}$. Therefore, there is a clear and urgent need for a structured, continued, state driven and committed education about the European Convention system for the protection of human rights and fundamental freedoms.

The implementation of the European Convention before the local courts and other authorities poses a new challenge, i.e. to use the case law as a source of law, which is not common feature of the legal tradition of the countries of former Yugoslavia. In the process of applying the Strasbourg case law, there are also challenges related to the lack of knowledge of foreign languages (English or French) by legal practitioners and the need to obtain proper translations of the key judgements of the Strasbourg court in order to bring them closer to local judges and other practitioners. Without the genuine and continuously committed approach by the state, without creating proper capacities and infrastructure, potential applicants, but also the respondent states will be faced with many legal challenges.

Slovenia, Croatia, Serbia, Montenegro and Northern Macedonia become bound by the European Convention after they ratified it, what is the usual situation when it comes to the entering into force of international treaties.

In Bosnia and Herzegovina, however, the situation was specific in this respect. European Convention (and its case law) has become directly applicable before the local courts since the entry into force of the General Framework Agreement for Peace (Dayton Agreement), i. e. 14 December 1995, and has priority over any other law ${ }^{8}$. It was an extremely difficult task for the local courts and other authorities to implement the provisions of this international agreement directly into the daily practice even before its formal ratification by the competent authorities of the newly established state, which occurred only in 2002, and without almost any prior substantial formal education of the practitioners.

\footnotetext{
${ }^{6}$ Louwrens R. Kiestra, The Impact of the European Convention on Human Rights on Private International Law, The Hague 2014.

${ }^{7}$ More details are available in the statistical report on the caseload in the Annual Report of the European Court of Human Rights at https://www.echr.coe.int/Documents/Annual_report_2018_ ENG.pdf, 09.10.2019.).

${ }^{8}$ Art. II, para. 2. of the Constitution of Bosnia and Herzegovina (i.e. Annex 4 to the Dayton Agreement).
} 
Therefore, in the transitional period of five years, some semi-international bodies were created: Human Rights Chamber and the Human Rights Ombudsman of Bosnia and Herzegovina, two constituent parts of the then Human Rights Commission for Bosnia and Herzegovina (established by the Constitution). This was a very similar model to the then Strasbourg system (the Human Rights Commission and European Court of Human Rights). International lawyers from the Commission and Court in Strasbourg were seconded to work in these two human rights bodies in Bosnia and Herzegovina, together with local legal experts, whom they gave an extensive training. Local lawyers gradually took over the responsibilities in handling the complaints on human rights violations the same way as they would be dealt with in Strasbourg 9 . This process was very challenging but revolutionary results have been achieved, having in mind the context in which those bodies have been operating in early years after the war in Bosnia and Herzegovina.

Similar problems can been observed in relation to the perspective accession of the countries of former Yugoslavia to the European Union. Though these countries have different pace towards this goal, it is clear that they all share the same problems. How to cope with an already existing ,acquis communaitare”, how to deal with a thousands of pages of different legislation, as well as with the case law of the European Court of Justice and how to organize the internal capacities to take over this demanding tasks ${ }^{10}$ (to create a separate ministry for European integrations, or create a specific task force within the existing ministries, to recruit staff with adequate educational background and knowledge of official languages of the European Union, etc.).

Since Slovenia and Croatia have joined the European Union earlier, their expertise and experience is very valuable for other states in the area. Regional cooperation projects resulted in significant improvement of the general situation as regards sharing know-how. Especially is worth mentioning that the translated materials containing relevant acquis have been distributed to other countries in the region by the Croatian authorities.

Obligation to apply the European Convention on Human Rights directly (including the case law) and to abide to the EU law may create certain difficulties and raise questions as to their interaction and applicability by the local courts and other institutions. Some already existing legal institutes have to be interpreted/ qualified in the new, ,pan European” sense (e.g., internal or national public policy is now complemented with European/common public policy ${ }^{11}$ ). In PIL acts in the region there is a new approach in drafting internal rules which impose obligation to apply international source of law. For example, in the new PIL Act of Croatia

\footnotetext{
${ }^{9}$ The author of the present paper was the Senior Deputy Human Rights Ombudsperson of Bosnia and Herzegovina from 1999 until 2003.

${ }^{10}$ Geert van Calster, European Private International Law, Oxford-Portland, Oregon 2016, 12.

${ }^{11}$ Krešimir Sajko, Međunarodno privatno pravo, Zagreb 2005, 372.
} 
it was prescribed that ,...the law applicable to contractual obligation is determined according to the EC Regulation no. 593/2008 ${ }^{12} \ldots$; the law applicable to non-contractual obligation arising from the traffic accident is determined according to the Hague Convention on Applicable Law for Traffic Accidents on Roads of 4 May $1971^{13}$...'. Similar provisions contain also the Montenegro PIL Act ${ }^{14}$, Draft PIL Act of Northern Macedonia ${ }^{15}$ and Draft PIL Act of Serbia ${ }^{16}$.

Some aspects of application of international sources of law can raise serious concerns among practitioners. For example, is there possibility to infringe one international obligation by obeying the other? Case law of the international courts dealt with the same issue and gave a positive answer to this question in some instances (cases before the ECHR in Povse v. Austria ${ }^{17}$, Avotins v. Latvia ${ }^{18}$, Neulinger and Shuruk v. Switzerland ${ }^{19}$, Bosphorus Hava Yollari Turizm ve Ticaret Aninim Sirketi v. Ireland ${ }^{20}$, etc.). ${ }^{21}$ In these and some other cases, European Court of Human Rights and/or European Court of Justice dealt with issues of point of contacts for bipatrides in private international law of its member states, the issue of recognition and enforcement of foreign judgments, the issue of returning the abducted child, the issue of length of enforcement in non contentious procedure, the relation between human rights protection guaranteed by the European Convention against the Charter of Human Rights of the European Union, the issue of public policy in the European context, etc.

One of the problems may be how to apply various international treaties properly in case when they do not contain provisions regulating their interaction and possible conflict. Which sources of international law have precedence and

${ }^{12}$ Article 25 para 1 of the PIL Act of Croatia (Official gazette of the Republic of Republic of Croatia No.101/2017.

${ }^{13}$ Article 27 of the PIL Act of Croatia.

${ }^{14}$ Article 57 and 58 of the Montenegro PIL Act of 2014 (Official gazette of the Republic of Montenegro No. 1/2014, 6/2014, 11/2014, 14/2014 and 47/2015.

${ }^{15}$ Article 59 of the draft PIL Act of the Northern Macedonia of 2015.

${ }^{16}$ Article 172 of the Serbian Draft PIL Act of 2014.

${ }^{17} \mathrm{https}: / /$ hudoc.echr.coe.int/eng\# \{\%22fulltext\%22:[\%22Povse\%20v.\%20Austria\%22],\%22 documentcollectionid2\%22:[\%22CHAMBER $\% 22, \% 22$ COMMITTEE $\% 22, \% 22$ DECISIONS $\% 22$ ],\%22itemid\%22:[\%22001-122449\%22]\}.

${ }^{18} \mathrm{https}: / /$ hudoc.echr.coe.int/eng\#\{\%22itemid\%22:[\%22001-163114\%22]\}.

$19 \mathrm{https} / / /$ hudoc.echr.coe.int/eng\# $\{\% 22$ fulltext $\% 22:[\% 22 \mathrm{Neulinger} \% 20$ and $\% 20$ Shuruk $\% 20$ v.\%20Switzerland\%22],\%22documentcollectionid2\%22:[\%22CHAMBER\%22,\%22COMMITTE E\%22,\%22DECISIONS\%22],\%22itemid\%22:[\%22001-90480\%22]\}.

${ }^{20} \mathrm{https}: / /$ hudoc.echr.coe.int/eng\# $\{\% 22$ fulltext\%22:[\%22Bosphorus\%20Yollari\%20v.\%20Ir eland\%22],\%22documentcollectionid2\%22:[\%22CHAMBER\%22,\%22COMMITTEE\%22,\%22D ECISIONS\%22],\%22itemid\%22:[\%22001-22048\%22]\}.

${ }^{21}$ Valerija Šaula, „Mogući problemi u primjeni medjunarodnih izvora medjunarodnog (privatnog) prava”, Pravna riječ, Banja Luka 55/2018, 521-539. Sanja V. Đajić, „The Achmea Cases-Story on Treaty Interpretation, Forum Competition and International Law Fragmentation“, Collected Papers of the Faculty of Law University of Novi Sad 2/2018, 502. 
how to apply several of them at the same time? The application of international sources of law before the domestic institutions is very important and should be in focus of doctrinarian research more often. Legal theory should develop necessary expertize and useful tools for the practitioners. The ultimate effect of such endeavor would be to help establishing a coherent and stabile system of proper application of international sources of law obligatory for the state in question.

The role of the highest judicial instances in this respect is pivotal. Solving the cases as an ultimate instance, these courts have also an educational role for the lower courts. That is why a high quality of judges appointed to these courts and their continued education is of crucial importance.

In the context of what has been said above, a number of processes in the former Yugoslav countries could be observed during last decades. The natural consequence of the process of global transition is the extensive legal reform which is not yet finished.

Especially this is the case in the countries that did not yet join the European Union. Those countries who joined this international regional organization (Slovenia and Croatia) were faced with direct implementation of a number of European laws (especially regulations) and did not have time or a need to adjust their internal legislation to those new obligatory sources of law.

However, other countries (Serbia, Montenegro, Northern Macedonia and Bosnia and Herzegovina) are trying to adjust their existing legal system to the European Union legal system as much as possible before the accession, in accordance with their respective Agreements on Stabilization and Association with the European Union.

Adjusting to the Private International Law of the European Union is a very challenging task ${ }^{22}$. Different approaches are possible: combination of the traditional rules and the common European rules, „legal transplantation” (which is easier for the legislator but does not guarantee sustainable and internally coherent regulation), two-track approach (separate regulation, depending on the fact if the issue is linked with a country member state of the EU or with a non-member state). Each approach can create difficulties for the legal practice.

\section{NEW PIL ACTS IN THE REGION/LEGAL TRANSPLANTS OR NOT}

The old PIL Act, as it was previously stated, was drafted by the very prominent scholars and practitioners who created legal rules with high level of abstraction and quality. Therefore, these rules are also able to address all new potential situations,

${ }^{22}$ Bernadet I. Bordaš, „Razvoj međunarodnog privatnog prava Unije u službi ostvarivanja njenih ciljeva“, Zbornik radova Pravnog fakulteta u Novom Sadu 4/2016, 1373-1390. The author uses the term „Europeanized Private International Law“, the part of the EU law that is binding for all member states of the EU and their courts. 
since one of its main principle was to find for the each legal situation the legal system that has the closest connection (this principle was incorporated in the conflict of law rules). For the situations that are not expressly regulated in the Act, the provision of resolving „legal gaps” was envisaged. Article 2 of the PIL Act provides that: "If this Act contains no provision concerning the law governing any of the cases referred to in Article 1, paragraph 1 of this Act, the provisions and principles of this Act, the principles of a legal order of this state (SFRY) and principles of private international law shall apply accordingly."

Despite the fact that the old PIL Act has been applied in former Yugoslav republics as new countries for decades, the activities to change it or adopt the new PIL Act have started some time ago.

Slovenia was the first country to accede to the European Union and changed the old PIL Act in $1997^{23}$. However, these changes were not substantial, due to the Slovenian obligation to apply Private International Law regulations of the European Union directly.

Northern Macedonia has adopted the new PIL Act in 2007 and changed it in $2010^{24}$. However, the Northern Macedonian authorities consider the need to have a completely new PIL Act and extensive activities in that regard have started already in 2015, when the work on new legislation have been considered. The idea is to align the existing PIL Act with the European Union Private International Law that emerged in the last decade.

Montenegro has adopted new Private International Law Act in 2014. This PIL Act was influenced by the newly adopted legislation in the region and drafted by the leading experts of Private International Law. The provisions of the Montenegro PIL Act represent modern and balanced approach of the old tradition concept and new legal challenges.

Republic of Croatia has adopted its new PIL Act in 2017 (after many years of extensive preparatory work ${ }^{25}$ ). This Act came into effect on 29 January 2019. Croatian PIL Act has a completely new approach in legislative methodology, since for the first time the provisions of the internal law do not give concrete answers to the legal practice but only refer to the international sources of law. The Croatian PIL Act is shorter than the old Yugoslav PIL Act, due to the methodology already mentioned and the intention to avoid unnecessary repetitions. It will be very interesting to see how this law will be applied in court and administrative practice since it is very challenging for the practitioners generally unused to apply international sources of law directly.

${ }^{23}$ Official gazette of the Republic of Slovenia No. 56/1999 and 45/2008.

${ }^{24}$ Official gazette of the Republic of Macedonia No. 87/2007 and 156/2010.

${ }^{25}$ Krešimir Sajko, Hrvoje Sikirić, Vilim Bouček, Davor Babić, Nina Tepeš, Izvori međunarodnog privatnog prava sa sudskom i arbitražnom praksom i tezama za zakon o međunarodnom privatnom pravu, Zagreb, 2001. 
In Serbia, the process of reforming the old Private International Law Act is underway. The working group, consisting of leading experts and university professors in the area of Private International Law, appointed in 2009, has prepared an extensive material and submitted it to the state administration for further proceedings in $2014^{26}$. However, this material has not yet been submitted to the parliamentary procedure.

Situation in Bosnia and Herzegovina is specific as the country itself. According to the Constitution of Bosnia and Herzegovina, only few expressly listed competences lie on the state level ${ }^{27}$. The presumption of competence is on the entities (Republic of Srpska and Federation of Bosnia and Herzegovina). Therefore, the matters regulated by the rules of Private International Law are within the competence of the entities and each entity in Bosnia and Herzegovina should adopt its own conflict of law rules and conflict of jurisdiction rules. Currently, both entities and Brčko District of Bosnia and Herzegovina are applying the old Yugoslav PIL Act ${ }^{28}$ and there is still no legitimate activity to start the process of drafting the

${ }^{26}$ https://www.mpravde.gov.rs/files/Nacrt\%20ZMPP\%20-\%20Ministarstvo.doc.

${ }^{27}$ According to Art. III of Annex 4 of the General Framework Agreement for Peace in Bosnia and Herzegovina (i.e. the Constitution of Bosnia and Herzegovina), clear division of responsibilities and competencies is in favor of the entities:"

1. Responsibilities of the Institutions of Bosnia and Herzegovina. The following matters are the responsibility of the institutions of Bosnia and Herzegovina:

(a) Foreign policy

(b) Foreign trade policy

(c) Customs policy

(d) Monetary policy as provided in Article VII

(e) Finances of the institutions and for the international obligations of Bosnia and Herzegovina

(f) Immigration, refugee, and asylum policy and regulation

(g) International and Inter/Entity criminal law enforcement, including relations with Interpol

(h) Establishment and operation of common and international communication facilities

(i) Regulation of inter-Entity transportation

(j) Air traffic control

......

3. (a) All governmental functions and powers not expressly assigned in this Constitution to the institutions of Bosnia and Herzegovina shall be those of the Entities.......

...... Coordination. Presidency may decide to facilitate inter-Entity coordination on matters not within the responsibilities of Bosnia and Herzegovina as provided in this Constitution, unless an Entity objects in any particular case......

...5. Bosnia and Herzegovina shall assume responsibility for such other matters as are agreed by the Entities, are provided for in Annexes 5 through 8 to the GFAP, or are necessary to preserve the sovereignty, territorial integrity, political independence, and international personality of $\mathrm{BaH}$, in accordance with the division of responsibilities between the institutions of $\mathrm{BaH}$.........

${ }^{28}$ The SFRY Private International Law Act continued to apply in both entities of Bosnia and Herzegovina since 1992 (Article 12 of the Constitutional Act for Implementation of the Constitution of the Republic of Srpska) and 1994 (Article 1 of the Act on Confirmation of Decrees with Legislative Power in Federation of Bosnia and Herzegovina). Regarding the Brčko District of Bosnia and Herzegovina, pursuant Article 76 of the Statute of 2000. 
new PIL acts. Once the process of changing the current laws or adopting the new ones starts, it would be advisable to coordinate the efforts and to produce as similar texts as possible in both entities. Similar approach was taken when civil procedure acts and enforcement procedure acts were adopted in 2003 in both entities in almost identical texts.

Unfortunately, due to difficult political situation and a lack of general consensus on the competence, authorities in Bosnia and Herzegovina adopted new laws and changed the existing ones under the influence of the ,international community", namely The High Representative, foreign embassies, governmental organizations and national and international non-governmental organizations. Unfortunately, many of these laws were adopted (imposed) contrary to the provisions of the Constitution regarding the division of competences. The proposed laws were drafted either predominately by international experts or with their active involvement in the process. The result of such situation is incoherence of the offered solutions with other laws and legal system of the local community in general due to the lack of understanding of its processes and specific needs. Sometimes there is a risk of adopting even unconstitutional solutions and the frequent changes of newly adopted laws ${ }^{29}$.

Imposed, imported and artificially transplanted legal solutions very often prove to be either non-implemented or implemented with difficulties. They generate internal conflict of laws because of the inconsistency of the solutions and result in frequent changes of the adopted laws.

Frequent changes of laws, as well as the abundance of complex and unclear regulations undermine the principle of rule of law and legal certainty, even jeopardize the principle of legality ${ }^{30}$. Legal system has to be coherent and consistent, to be able to create legal community ${ }^{31}$.

Legal tradition of the former Yugoslav republics is based on the principles of Roman Law, which were adjusted to the then existing economic and social needs, but, above all, it was the product of human spirit, part of global view on the world and ,philosophy" of that time, its religion and ethics ${ }^{32}$. These components should not ever be underestimated.

${ }^{29}$ The Constitutional Court of the Republic of Srpska has declared certain articles of the Law on Notaries Public unconstitutional since they envisaged that provisions of any other law which is not in accordance with the Articles 68 and 69 of the Law on Notaries Public cease to apply after entry into force of the aforementioned law (Judgement of the Constitutional Court in case U-60/06, published in the Official gazette of the Republic of Srpska No. 74/2007). The Constitutional Court held that it is unconstitutional to give precedence to a particular law over the other. Legislator should take care of consistency between the laws that regulate the same or related legal situations in order to prevent their conflict. There is no ground in the Constitution to provide provisions that would give priority in practice to one law over another.

${ }^{30}$ Miodrag Jovičić, Zakon i zakonitost, Život pravnih propisa, Beograd 1977, 249-250.

${ }^{31}$ Hans Kelzen, Čista teorija prava, Beograd 2000, 187.

32 Žika Bujuklić, Rimsko privatno pravo, Beograd 2015, 3. 
Drafting laws is a very serious and hard task. It takes erudition of the drafters and involvement of practitioners. If this process would be initiated and carried out contrary to the constitutional provisions, with inadequately competent and dedicated experts, it will have no success.

\section{NOVELTIES IN THE NEW PIL ACTS/RADICAL REFORM OR NOT}

In the process of changing the Private International Law in the countries of former Yugoslavia, some new concepts and institutes were introduced as a response to the development in contemporary international private law relations and especially in international business transactions.

First, the title of the respective law changed from ,Act on Resolution of Conflict of Laws with Other Countries in certain Relations” to „Private International Law Act". This change represents the new paradigm of the concept, structure and importance of this branch of law in the era of globalization and internationalization in every field of life. This title was proposed also by the working group almost forty years ago, when the PIL Act was submitted to the parliamentary procedure.

Due to the new circumstances, after the dissolution of the common state, the changes were inevitable. What was previously the relation of internal character has now become a relation with foreign (international) element and rules of choice of law and choice of jurisdiction need be applied before dealing with the substance of the case. The movement of goods and persons has dramatically increased after the war. Almost each former Yugoslav family was affected with some private international law problem (legal status of foreign citizens, marriage concluded in one state was divorced in the other, family relations and obligations are effected abroad, inheritance of goods situated in foreign country, property located on the territory of different countries, access to a foreign court, recognition of foreign judgements, use of foreign public documents, emerging of new officials: public notaries and documents produced within their competence are used abroad, etc.).

In drafting the new private international law acts in former Yugoslav countries, common features are evident. It is obvious that drafters of the mentioned laws oscillated between extensive legislation (what might be easier for the practitioners, who would like to have all the provisions of PIL in one act) as in Serbia or short laws with provisions that are necessary and those which would direct practitioners to other sources of law (international or domestic) as in Croatia.

The drafters used some of the recent legislative efforts as a model, i.e. Belgian Private International Law Act of 2004, Bulgarian Private International Law Act of 2005 and Private International Law Act of Montenegro of 2014. The PIL acts were 
clearly also influenced by the relevant European Union regulations and conventions adopted in the Hague Conference on Private International Law. However, reasonable balance has been achieved between the legal tradition in this area and new legal challenges or necessary changes.

Some obsolete institutes have been omitted (fraus legis) or some of them have been limited to a reasonable extent ( revoi $^{33}$, party autonomy, reciprocity, information of foreign applicable law, solution regarding double/multiple nationality, lis alibi pendens), the structure and order of provisions of the laws were changed to be more logical and easier to apply by practitioners. Private International Law usual terms, instead of obsolete ones, are used: conflict of law rules, public policy, most significant relationship (proper law). Autonomous definitions are given for the institutes that are newly introduced: habitual residence, rules with direct application (mandatory rules), forum non conveniens (excessive international jurisdiction).

As predominantly countries of emigration, the legislators of the former Yugoslav countries retained the „,nationality” principle as one of the leading connecting factors in conflict of law rules in their new PIL acts. However, some new solutions were introduced in the area of personal law.

One of the new institutes is "habitual residence”, which replaced or supplemented the traditional concept of "domicile”. The „old" domicile concept requires that the natural person resides in a specific place, but also to have an intention to remain there permanently. The „habitual residence" (accompanied by the autonomous definition of that concept) could be more useful. Therefore, the fact of residing a certain period of time (habitually) in one place (app. 6 months) would suffice to establish a "habitual residence" there ${ }^{34}$. This new point of contact for determining the applicable law and international jurisdiction could be widely used to replace the former one, i.e. domicile, or can be introduced parallel to the existing one in some justified cases.

${ }^{33}$ Extensive elaboration about this institute in the European Union Private International Law instruments is presented in: Jan von Hein, „Renvoi in European Private International Law:, General Principles of European Private International Law (ed. Stefan Leible), Kluwer Law International BV, The Netherlands 2016, 227-273. Detailed explanation about the approach concerning the renvoi in the court practice of the United Kingdom is accessible in Geoffrey Chevalier Cheshire, Peter Machin North, Private International Law, Butterworth \& Co (Publishers) Ltd, London 1987, 57-73. For the detailed explanation of the principle of renvoi in former Yugoslav practice and theory, see in Tibor Varadi, Bernadet Bordaš, Gašo Knežević, Vladimir Pavić, Međunarodno privatno pravo, Beograd 2007, 135-149.

${ }^{34}$ Marc-Philippe Weller, Bettina Rentsch, „Habitual residence“: A Plea for „Settled Intention“, General Principles of European Private International Law (Stefan Leible, ed.), Kluwer Law International BV, The Netherlands 2016, 171-187; Krešimir Sajko, Međunarodno privatno pravo, Zagreb 2005 130-134; Maja Kostić-Mandić, Međunarodno privatno pravo, Podgorica 217, 252-257; Maja Stanivuković, Mirko Živković, Međunarodno privatno pravo, Beograd 2010, 113-117; Valerija Šaula, Osnovi Međunarodnog privatnog prava Republike Srpske, Banja Luka 2019, 118; Poliksena Gavroska, Toni Deskoski, Međunarodno privatno pravo, Skopje 2011, 297; T.Varadi et al, 274. 
All new PIL acts have envisaged, ,general escape clause”, rule that allows the competent authority, in the specific circumstance of the concrete case, to apply the law that has closer connection than the law prescribed by the legislator in the „fast and hard" conflict of law rules ${ }^{35}$. Though one of the general principles of every conflict of law rule is the principle of ,proximity" (the closest connection), sometimes the fast and hard rules are too tight for the concrete situation. The use of such „legal standards" should be applied only in exceptional cases, since they may create legal uncertainty for the parties and also some confusion for the practitioners who are not traditionally used to them ${ }^{36}$.

In the everlasting effort to balance between ,nationalism and internationalism", between internal and international harmony of decisions, legislators should be aware that problem remains in actual practice of courts and other state authorities which are not usually inspired by internationalism of any kind (they ignore the presence of international element in disputes) ${ }^{37}$.

Basic institutes of Private International Law (remission and transmission-renvoi; public policy/international/European public policy ${ }^{38}$; overriding mandatory rules of foreign state, burden of proof of foreign law, reciprocity, etc.) have been transformed and adjusted to contemporary needs.

Limited party autonomy is introduced in the areas where it was not possible before (tort, marital relations, divorce, inheritance, etc.) under the influence of the European Union regulations.

Status of aliens (foreign citizens) was improved in terms of wider accessibility of their rights.

New conflict of law rules were introduced for determining applicable law for: personal name ${ }^{39}$, intellectual property, securities, infringement of market competition, etc.

Procedure of recognition and enforcement of foreign judgements is substantially reformed with the intention to secure the basic procedural guarantees for all

${ }^{35}$ Oliver Remien, Closest Connection and Escape Clauses, General Principles of European Private International Law (Stefan Leible, ed.), Kluwer Law International BV, The Netherlands 2016, 211-224; Maja Kostić-Mandić, Opšta klauzula odstupanja od mjerodavnog prava-u savremenom međunarodnom privatnom pravu-, Podgorica 2012; P. Gavroska, T. Deskoski, Međunarodno privatno pravo, Skopje 2011, 279; M. Stanivuković, M. Živković, Međunarodno privato pravo, Beograd 2010, 296;

${ }^{36}$ Kurt Nadelmann, ,Impressionism and Unification of Law. The EEC Draft Convention on the Law Applicable to Contractual and Non Contractual Obligations", American Journal of Comparative Law (AJCL) 24/1976.

${ }^{37}$ M. Stanivuković, M. Živković, „International Encyclopedia of Laws”, Kluwer Law International, Hague-London 2001, 23.

${ }^{38}$ For English public policy see in John G. Collier, Conflict of Laws, Cambridge 2004, 36.

${ }^{39}$ Maja D. Stanivuković, „Lično ime deteta u srpskom međunarodnom privatnom pravu“, Zbornik radova Pravnog fakulteta u Novom Sadu, 1/2017, 26-28; M. Kostić-Mandić, Međunarodno privatno pravo, Podgorica 2017, 271. 
the participants but also to make this procedure as efficient and expeditious as possible.

This limited overview of the new development in the area of Private International Law of the region shows that it is possible to reconcile the need to do extensive legal reform but also to retain the basic principles of the former joint legal tradition, clarity, dominance of fast and hard rules, consistency, original approach adjusted to the needs of a specific community, etc.

It is very important for the quality and effectiveness of any legislative result to undertake coordinated efforts and to strive to regional harmonization, first of all to the benefit of private law subjects in legal transactions with international element but also to achieve overall legal predictability, coherence and stability.

One of the prerequisites to achieve the best results is to develop necessary mechanisms within the respective state authorities to be able to cope with the demands of a very complex and difficult tasks. It takes competent human resources, adequate material resources, constant education and stimulation, involvement of practitioners and scholars to achieve the best results that correspond to the needs of their respective community. Changes of the existing laws should be carefully planned and prepared after a thorough analysis by specialized experts in the specific field and undertaken only when it is necessary. Stability and coherence of legal order should be preserved.

\section{CONCLUSION}

Private International Law is a very important discipline of the legal science and a very important branch of law in daily life. Having that in mind, states should invest additional efforts to make its operation successful, not just to satisfy the legitimate expectations of the parties but also to be able to provide stability of legal relations in all interested countries.

Legal certainty and predictability, accommodating the legitimate expectations and needs of the parties, legal stability and recognition of public documents produced in one state are the overall goals of the complex mechanism of Private International Law.

Continued education and specific expertise of practitioners is crucial. Perhaps specialization of the highest court judges could be considered, since they would be able to educate other colleagues in specific areas. That would contribute to coherent, consistent and stabile legal system. Supreme courts in the states of the region should have a pivotal role in education and setting examples of proper application of international sources of law, especially the case law of the European courts.

It is very important that the case law of the local courts in disputes with international element is more accessible to the public, especially to the scholars. 
The court administration should be reformed with a view to register cases with international element differently than the other cases, what would help scholars to follow the development of the case law in the specific field and produce useful comments and guidelines for the future practice.

The changes of the existing laws should be carefully planned and put into hands of experienced scholars and practitioners, who would be able to distance themselves from the interest of daily politics. By producing long lasting and coherent legal solutions, they should try to the most possible extent to preserve legal tradition as an element of national identity, but also to address the existing and future legal challenges.

States should include the appropriate level of knowledge about the protection of human rights and fundamental freedoms in their education systems, already from early age, in primary and secondary education and onwards. University education on all there levels (bachelor, master and doctoral degree) should integrate knowledge about the Strasbourg Court protection mechanism in the curricula through compulsory and/or elective courses, not only at the faculties of law but in all study programs accordingly. It is also very important to organize and implement life-long education about the European Convention for legal practitioners on specific topics, depending on the need of every community.

Knowledge about the European Union and its legal system should be adequately integrated in all levels of education, with special emphasis on the higher education.

If the above tasks would be carried out properly, each state would be able to address new legal challenges successfully but also to preserve the values of the common legal tradition. Thus, they can contribute to the legal certainty for the parties, international stability of legal solutions, mutual recognition of court judgements and other public documents, what would ultimately lead to the strengthening mutual trust and confidence in the neighboring legal systems of the region.

\section{REFERENCES}

Bernadet I. Bordaš, „Razvoj međunarodnog privatnog prava Unije u službi ostvarivanja njenih ciljeva“, Zbornik radova Pravnog fakulteta u Novom Sadu, 4/2016.

Vilim Bouček, Europsko međunarodno privatno pravo u eurointegracijskom procesu i harmonizacija hrvatskog međunarodnog privatnog prava, Zagreb, 2009.

Žika Bujuklić, Rimsko privatno pravo, Beograd, 2015.

Geert van Calster, European Private International Law, Oxford and Portland, Oregon, 2016.

Geoffrey Chevalier Cheshire, Peter Machin North, Private International Law, Butterworth \& Co (Publishers) Ltd, London, 1987.

John G. Collier, Conflict of Laws, Cambridge, 2004. 
Sanja V. Đajić, „The Achmea Cases-Story on Treaty Interpretation, Forum Competition and International Law Fragmentation", Collected Papers of the Faculty of Law University of Novi Sad 2/2018.

Poliksena Gavroska, Toni Deskoski, Međunarodno privatno pravo, Skopje 2011.

Jan von Hein, „Renvoi in European Private International Law”, General Principles of European Private International Law (ed. Stefan Leible), Kluwer Law International BV, The Netherlands 2016.

Miodrag Jovičić, Zakon i zakonitost, Život pravnih propisa, Beograd 1977.

Hans Kelzen, Cista teorija prava, Beograd 2000.

Louwrens R. Kiestra, The Impact of the European Convention on Human Rights on Private International Law, The Hague 2014.

Maja Kostić-Mandić, Opšta klauzula odstupanja od mjerodavnog prava-u savremenom međunarodnom privatnom pravu-, Podgorica 2012.

Maja Kostić-Mandić, Međunarodno privatno pravo, Podgorica 2017.

Kurt Nadelmann, „Impressionism and Unification of Law. The EEC Draft Convention on the Law Applicable to Contractual and Non Contractual Obligations", American Journal of Comparative Law (AJCL) 24/1976.

Oliver Remien, „Closest Connection and Escape Clauses“, General Principles of European Private International Law (ed. Stefan Leible), Kluwer Law International BV, The Netherlands, 2016.

Krešimir Sajko, Hrvoje Sikirić, Vilim Bouček, Davor Babić, Nina Tepeš, Izvori međunarodnog privatnog prava sa sudskom i arbitražnom praksom i tezama za zakon o međunarodnom privatnom pravu, Zagreb, 2001.

Krešimir Sajko, Međunarodno privatno pravo, Zagreb 2005.

Maja D. Stanivuković, „Lično ime deteta u srpskom međunarodnom privatnom pravu“, Zbornik radova Pravnog fakulteta u Novom Sadu, 1/2017.

Maja Stanivuković, Mirko Živković, „International Encyclopedia of Laws”, Kluwer Law International 2001.

Maja Stanivuković, Mirko Živković, Međunarodno privatno pravo, Beograd 2010.

Valerija Šaula, Osnovi Međunarodnog privatnog prava Republike Srpske, Banja Luka 2019.

Valerija Šaula, „Mogući problemi u primjeni medjunarodnih izvora medjunarodnog (privatnog) prava", Pravna riječ, Banja Luka, 55/2018.

Tibor Varadi, Bernadet Bordaš, Gašo Knežević, Vladimir Pavić, Međunarodno privatno pravo, Beograd, 2007.

Marc-Philippe Weller, Bettina Rentsch, „Habitual residence“: A Plea for „Settled Intention", General Principles of European Private International Law (ed. Stefan Leible), Kluwer Law International BV, The Netherlands, 2016.

https://www.echr.coe.int/Documents/Annual_report_2018_ENG.pdf 
Dr Valerija E. Šaula, redovni profesor

Univerzitet u Banjoj Luci

Pravni fakultet

Valerija.saula@pf.unibl.org

\section{Reforma međunarodnog privatnog prava u državama nastalim na području bivše Jugoslavije - Novi pravni izazovi naspram pravne tradicije ${ }^{40}$}

Sažetak: Države nastale na području bivše Socijalistučke Federativne Republike Jugoslavije (SFRJ) postigle su ogroman napredak u reformisanju svojih pravnih sistema, uprkos nesrećnim posledicama rata. Iza ovog procesa stoji potreba da se poštuju nove međunarodne obaveze (posebno Evropska konvencija o zaštiti ljudskih prava i osnovnih sloboda), a drugo da se, što je moguće više, izvrši usklađivanje sa pravom Evropske unije (acquis communaitaire).

Jedna od sličnosti svih ovih država je jasna namera da se reformiše njihovo međunarodno privatno pravo. U eri globalizacije, široke cirkulacije (kretanja) ljudi, roba i usluga, stranih sudskih $i$ arbitražnih odluka i drugih javnih isprava, pravila o rešavanju sukoba zakona i pravila o rešavanju sukoba jurisdikcija $u$ privatnopravnim odnosima postaju sve važnija u svakodnevnom životu i pravnoj praksi. Postoji jaka potreba za harmonizacijom pravila međunarodnog privatnog prava. Takođe, postoji potreba i za posebnom vrstom stručnog znanja (ekspertize), možda i specijalizacije sudija, koji bi onda obučavali svoje kolege, kako bi se postigla koherencija, konzistencija i stabilnost pravnog sistema i poštovanje u međunarodnoj zajednici.

$U$ radu se detaljnije razmatraju pitanja reforme međunarodnog privatnog prava u državama nastalim na području bivše SFRJ. Rad pokušava da pokaže da je moguće pomiriti potrebu da se izvrši ekstenzivna pravna reforma ali i da se očuvaju bazični principi prethodne zajedničke pravne tradicije.

Ključne reči: reforma međunarodnog privatnog prava; zakon o međunarodnom privatnom pravu; bivša SFRJ; Evropska konvencija o zaštiti ljudskih prava i osnovnih sloboda; Evropska unija.

Datum prijema rada: 22.10.2019.

${ }^{40}$ Rad je prezentovan na Međunarodnoj naučnoj konferenciji Pravna tradicija i novi pravni izazovi, održanoj 03. i 04.10.2019. godine na Pravnom fakultetu Univerziteta u Novom Sadu. 